\title{
公害対策の現状と問題点 （とくに大気汗染について）
}

正会員絉野昭*同 ○渡辺治郎**

序: 公害問題はかぎられた当事者間のトラブルの範国 をこえ，地域的に被害を発生（産業公害）して開発計画 上の重大な問題となったり，また不特定多数が発生源と なる梁刻な都市問題（都市公害）に転化している。

都市計画に対し，その計画の検討あるいは対策をもと める他部門からの要請が最近とみに強い。

（公害現象の代表例）大気污染，水質污湌，地盤沈下 経音・振動……㣗らの媒体は空気，水，目体であり関 係する学閒分野は多岐にわたる。

（大気污染について）被害状況からみて，“広域活染”… …市街地全体が対象となる恒常的污染スモッグ, $\mathrm{SO}_{2}$ な ぞ。“局地污染”.......がきられた地区に一時的高濃度游染 ばい塵， $\mathrm{SO}_{2}$, 覀臭など。

公害の実態把握とその方法についてはまだ不明確な点 があまりに多い。被害についても，一般常識はともかく 発生源からみた污染の影響圈域など, 刘策上の諸指標は 未知である。

問題点……11)発生源の実態, (2)市街地（都市化）の実 態, (3)大気の流体力学的メカニズムと建築群・市街地形 態および工業地带の配置,レイアウトとの相互関係，(4) 地形・気象等の自然条件との関係, 微気象的問題。

1. 準備されている対策の方向 (とくに新産業都㠴・工 特地域に対して)：新らしく大規模な工業地带の建設が 予定されている地域におるる, 開発にさきだつ事前調查 としては, 現地での排ガスの拡散現象の実測, 実験的手 法(模型を用いた風洞実験) が重点的に実施されている。

○実測調查 (1)地上……多数地点での大型発煙简に よる。(2)空中……・リコプタ一発炡, 打上げ吊煙, 風船 放流による気流動態，逆転層調查。

○風洞実験 局地モデル (1)系流し試験……地表面， 建物表面の観察，(2)乱れ域試験……地形お゙び建築群の 周辺状況，(3けむり試䮦……排ガスの上昇, 流れ。広域 モデル (4)変色試験……排ガスの地表到達領域, (5)定量 試験 $\cdots \cdot . \cdot . \mathrm{SO}_{2}$ 等の地表濃度。

○問題となる事項 (1)地域開発計画……業地・住宅 地の配置, 工業地のレイアウト, 地域のマスタープラン。 (2)工場建設計画……設俑計画, 諸施設の配置計画, 操業・ 運営計画。(3)地利用現況……業・農業・住宅・市街

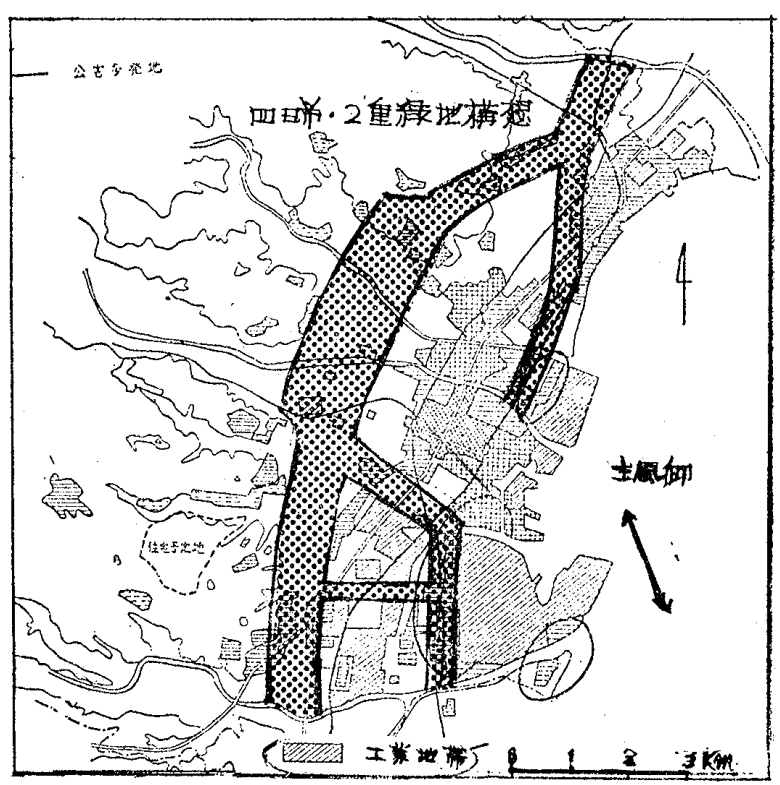

図一1 四日市二重緑地構想

地との, 開発地区との関係。(4)地形・気象など自然条件 ……風向・風速，大気安定度ほか, 微気象問題。

\section{2. 石油化学工業都市 (四日市) の事例}

(1)これまでの調查・钯告

$\mathrm{SO}_{2}$ を主原因とする四日市の公害に対して，通産省・ 厚生省が㗢告を出したが，特に都市計画に関連して次の 事項が含まれている。

○公害対策の観点からする市街地の改造

○住宅と学校の移転

○工場・住宅地間の広範囲な緩衝地带の設置

○四日市都市計画の改訂

(2)都市計画から提案した対策について

$\left.\begin{array}{rl}\text { 作業段階 I 被害の赛態……現地污染実測 } \\ \\ \text { II 地域の実態……市街化の判定 }\end{array}\right\}$ 風洞実験 III対策の提示……地区改造,二重緑地構想， 人口の密度計画

閭題点……(1)污染気流と地勢・市街地・建物配置との 関係, (2)地域構造分析の方法的課題, (3)再開発の形態・ 手法・问能性の検討, (4)マスタープランにおける土地利 用計画の害施と公害予測調查とのつきあわせ, (5)環境条 件の将来変動を前提とする現況把握

\footnotetext{
* 建設省建築研究所都市計画研究窒長 - 工博 $* *$ 東京大学大学院生
} 